\title{
Can we increase adolescent growth?
}

Jean Claude Carel

Department of Pediatric Endocrinology and INSERM U561, Groupe Hospitalier Cochin-Saint Vincent de Paul and Faculté Cochin-Université Paris V, Paris, France

(Correspondence should be addressed to J C Carel, Pediatric Endocrinology and INSERM U561, Groupe Hospitalier Cochin-Saint Vincent de Paul, 82 Avenue Denfert Rochereau, 75014 Paris, France; Email: carel@paris5.inserm.fr)

\begin{abstract}
Adolescent growth represents $15-20 \%$ of adult height and has been the focus of several treatment interventions, aiming at increasing the amplitude of the adolescent spurt. Importantly, pre- and early puberty are times when patients and families seek medical help and when estimates of adult height are more accurate than in younger children. We review the current approaches aimed at increasing pubertal growth in short children and knowledge about their results and risks. GnRH agonists, when used outside the context of precocious puberty, induce a modest gain $(4 \mathrm{~cm})$ when they are used for more than 3 years. Their effects on bone mass, body composition and possibly on psychosocial parameters limit their use. Several trials have now shown that GH can increase adult height of short adolescents with idiopathic short stature or born small for gestational age. However, the amplitude of the effect is modest and of dubious clinical significance. Lastly, the association of both approaches is rather popular among pediatric endocrinologists but still lacks a definite demonstration of its efficacy. In conclusion, we have gained insight in the median effects of some of these treatments and overoptimistic initial expectations are now refocused. However, we still have a long way to go before we truly evaluate the factors affecting the variable individual responses to these treatments, their clinical significance and their cost-benefit balance.
\end{abstract}

European Journal of Endocrinology 151 U101-U108

\section{Introduction}

Pubertal growth represents $15-20 \%$ of adult height and has been the focus of several treatment interventions, aiming at increasing the amplitude of the pubertal spurt. Importantly, pre- and early puberty are times when patients and families seek medical help to evaluate height prognosis and ultimately try to increase adult height if they see the estimate as unfavorable. In addition, at this time in life, adult height prognoses are more accurate than in younger children, allowing targeting of medical intervention on the right individuals. Here we will review current approaches aimed at increasing pubertal growth and knowledge about their results and risks.

\section{Normal pubertal growth}

Pubertal growth represents approximately 15-20\% of adult height and precedes the fusion of growth plates. Before puberty, growth does not proceed at a constant rate as generally thought, but declines progressively with age. This explains why growth velocity can be 'physiologically' low in delayed puberty and why the inflexion point can be missed if puberty occurs very early, since 'prepubertal' growth can be rather rapid.
As examples, the 95\% confidence interval (CI) of growth velocity in prepubertal girls is 5.1 to $9.3 \mathrm{~cm} /$ year at 4 years and 3.9 to $7.3 \mathrm{~cm} /$ year at 8 years. After the prepubertal decline, growth velocity increases and reaches a peak, on average 22 months later, and declines (1). The total amplitude of the pubertal spurt (from the inflexion point to adult height) is not a fixed value and varies negatively with the age of onset of puberty $(1,2)$. Similarly to the amplitude of the growth spurt, peak growth velocity, one of its components, decreases with age at pubertal onset (1-3). Therefore a compensatory mechanism occurs where individuals with earlier puberty grow less before puberty and more during puberty while those with late pubertal development start their puberty taller but grow less during puberty. Whether this compensation is complete and whether those who enter puberty at the earlier end of the normal spectrum end up shorter than those who mature later is still a matter of debate (4). Normal Spanish boys who entered puberty (G2 stage) at mean ages of 11,13 or 15 years reached similar mean adult heights (5). In contrast, a study (3) performed in a large series of American girls indicated a higher adult height in girls with late $(>12.9$ years $)$ vs early $(<11.7$ years $)$ age at menarche. The median difference was 2.6 and $1.7 \mathrm{~cm}$ in white and black girls respectively. Interestingly, in childhood and 
early adolescence, early maturers were taller, had higher body mass index (BMI) and thicker skinfolds than later maturers. This points to the tight interactions between fat mass and pubertal development. The other variables affecting the pubertal growth spurt have not been recognized so far, but it is likely that characteristics of the growth plate will be identified.

Another important point to consider is the concordance between the growth spurt and clinical pubertal development $(1,6,7)$. Most investigators use clinical pubertal development as landmarks for pubertal growth, hindering this analysis. However, when using auxological parameters to identify the spurt, it is possible to evaluate its concordance with clinical Tanner stages. In girls, the acceleration of growth generally occurs before or during the first year of breast development. In boys, the acceleration of growth occurs later, in general during the second year of pubertal development. There are of course large individual variations around this median pattern. In girls, peak growth velocity occurs at stage B2 in $40 \%$ of individuals, B3 in $30 \%$, B4 in 20\% and B1 (before breast development) in $10 \%$ (1). Similarly, in boys, peak growth velocity occurs at stage G3 in $60 \%$ of individuals, G4 in 28\%, G2 in $8 \%$ and G5 in $4 \%$ (1). The mechanistic basis of these variations is essentially unknown. However, current concepts on the respective roles of estradiol and testosterone on the growth plate explain the different tempo of pubertal growth in boys and girls (8). Observations made in patients with androgen or estrogen resistance or with aromatase deficiency indicate clearly that in both sexes estradiol is the active hormone involved in bone metabolism and growth plate maturation. The sexual dimorphism in the tempo of pubertal growth is likely to be due to the delay needed for estradiol level to reach a certain threshold after aromatization from testosterone in boys (8).

Another important component of pubertal growth relates to the amount of body fat. The acceleration of growth and puberty associated with common obesity is well known and some of the variations of pubertal components are probably related to the progressive increase in body fat in the population. The influence of childhood adiposity on pubertal growth has been analyzed in a longitudinal study of normal children (9). The evolution of height in standard deviation between the age of 8 and adult height was taken as a (relative) measure of the adolescent growth spurt and was related to the evolution of BMI between the ages of 2 and 8 . The findings indicate that an additional gain of $1 \mathrm{BMI}$ point $(+1 \mathrm{~kg})$ decreases the adolescent growth spurt by a mean of $0.5 \mathrm{~cm}$ in girls and $0.9 \mathrm{~cm}$ in boys. The 'reduced' adult height in girls with early vs late maturation discussed above (3) probably relates to a similar mechanism. The aromatization of androgens of adrenal or gonadal origin by the adipose tissue is probably involved.
Other non-endocrine factors certainly affect the kinetics of growth plate maturation around the age of puberty. Although their role in normal physiology is not known, two pathological examples highlight their importance. FGFR3, one of the fibroblast growth factor receptors, is expressed in the growth plate and is involved in several constitutional bone disorders leading to short stature, including achondroplasia and hypochondroplasia $(10-12)$. In these disorders, activating mutations of the receptor lead to premature closure of the epiphyses and to short stature. Conversely, in a mouse model, targeted disruption of the receptor leads to tall stature, indicating an influence of FGFR 3 on the regulation of growth plate physiology (13). Pseudohypoparathyroidism is another pathological example where premature closure of the growth plate occurs in the absence of a sex-steroid signal. In this disease, loss of function mutations of GNAS1, the gene encoding for the alpha-subunit of the regulatory Gs protein, leads to resistance to parathyroid hormone and other hormones (14-16). In addition, 'ectopic' bone formation leads to subcutaneous calcifications and accelerated growth plate fusion, leading to the well-known metacarpal shortness and to the lack of pubertal growth spurt in these patients. Similar but more subtle variations in growth plate function might contribute to the adolescent growth spurt and have recently been reviewed (17).

\section{The short child at onset of puberty}

Although it is obvious that short stature should be evaluated as early as possible, many short stature patients present around pubertal ages, after the age of 9 in girls and 11 in boys. These patients need a complete workup that is beyond the scope of this review and it is not rare to identify at this stage acquired conditions such as craniopharygioma, inflammatory bowel diseases, celiac disease or constitutive conditions such as Turner's syndrome, skeletal disorders (short stature homeobox (SHOX) gene defects, hypochodroplasia etc.). However, in most cases, a diagnosis of idiopathic short stature or constitutional delay of growth and puberty is made, opening the question of the adult height prognosis and its adequacy with the familial target height and with the individual's wishes.

In such cases, the Bayley-Pinneau method is the most popular one to evaluate the growth prognosis. We have been able to evaluate the accuracy of the method in a series of 63 children, who were seen around the age of 11 and were followed to adult height (Table 1). There is a trend for overprediction in boys and underprediction in girls and in both cases a very wide inter-quartile range $(6 \mathrm{~cm}$ in boys, $8 \mathrm{~cm}$ in girls). Although the method looks rather satisfactory overall in clinical studies, the accuracy of prediction is very insufficient for individual cases. In addition, identifying the cause of the short stature or limited adult 
Table 1 Difference between predicted and actual adult height $(\mathrm{cm})$ in untreated children evaluated around the age of puberty.

\begin{tabular}{lcccccc}
\hline & $\boldsymbol{n}$ & Median & 1st quartile & 3rd quartile & Min & Max \\
\hline Boys & 32 & -1.3 & -4.0 & +2.0 & -19 & 5 \\
Girls & 31 & +1.2 & -1.9 & +6.0 & -10 & 9
\end{tabular}

height prognosis should be a priority, since it will impact on the precision of the prognosis; as an example a short prepubertal girl with Turner syndrome will have a far worse growth prognosis than a girl with similar auxological characteristics and constitutional short stature.

Although in most cases, regular follow-up and reassurance are the best options, several therapeutic approaches have been discussed in short patients at the onset of puberty. It is clear that at this point many of these treatment options have not been fully validated and should not be considered as a standard of care unless they have been approved for use by regulatory authorities in a given country.

\section{Gonadotropin-releasing hormone (GnRH) agonists in short children at onset of puberty}

The depot forms of GnRH agonists efficiently suppress the gonadotropic axis and the introduction of 3month depot forms has made their use even easier than with the traditional 1-month depot forms (18). In precocious puberty, the median height gain measured by the Bayley-Pinneau method ranges from 3 to $10 \mathrm{~cm}$ in recent studies (19), with several factors affecting height outcome. The results observed in precocious puberty and the hope that interrupting puberty might increase adult height has led to several attempts to use GnRH agonists in patients other than those with strict criteria for precocious puberty, in particular children with normal puberty and poor growth prognosis due to idiopathic short stature.

Only a few studies have presented adult height data after treatment with GnRH agonists alone (Fig. 1). In our study, 31 girls with idiopathic short stature and pubertal onset around the age of 12 were treated for an average of 1.9 years. The results were disappointing since the increase of adult over pretreatment-predicted height was $1 \pm 2.3 \mathrm{~cm}(P<0.02)(20)$. More importantly, growth velocity markedly declined during treatment and the height deficit increased by 0.4 SDS on average in these already short girls. Although no psychological outcome was evaluated in our study, treatment was poorly perceived by many of the girls. In the recent and long awaited NIH study, the same issue was addressed through a placebo-controlled randomized study (21). The population was quite heterogeneous, with half of the patients diagnosed as having idiopathic short stature and the other half having various conditions affecting
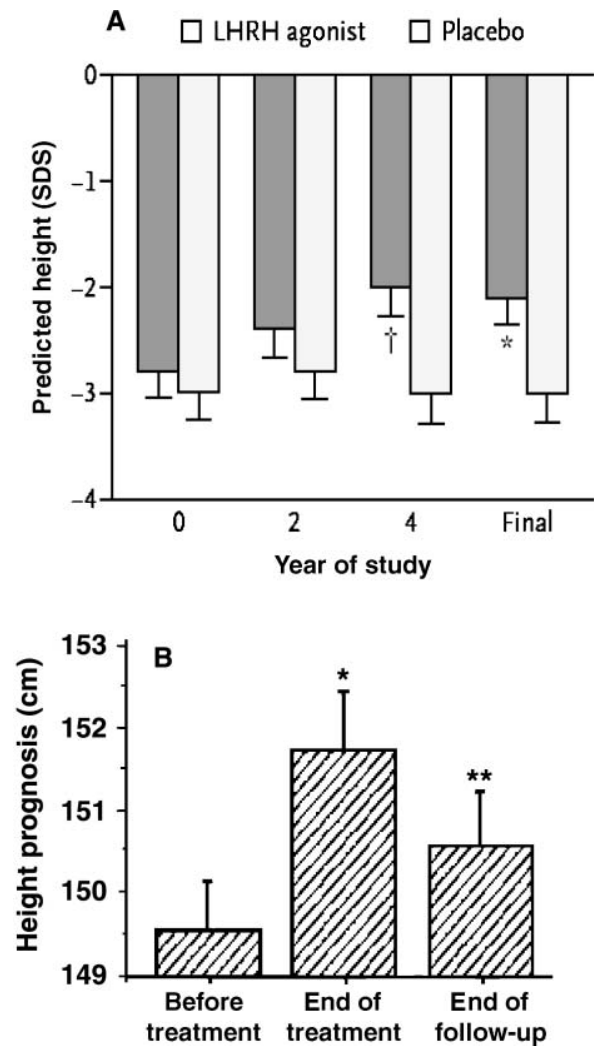

Figure 1 Evolution of height prognosis during treatment with a $\mathrm{GnRH}$ agonist in children with short stature. (A) Mean treatment duration $=3.5$ years, $n=25$ (LH-RH agonist) and 22 (placebo); ${ }^{\star} P<0.05, \dagger P<0.01$; means \pm S.D. are shown. Adapted from (21), with permission from the Massachusetts Medical Society, copyright 2003; (B) mean treatment duration $=1.9$ years, $n=31$, mean \pm S.D. are shown. Adapted from (20), with permission from The Endocrine Society, copyright 1996. LHRH, luteinizing hormone-releasing hormone.

growth, ranging from Cushing's disease to bone disorders. One third of the adolescents were also treated with growth hormone $(\mathrm{GH})$. The mean duration of treatment was 3.5 years and treatment was stopped around the age of 15.5 years in girls and 17 years in boys. Covariance analysis of adult height SDS, adjusted on sex, GH treatment, baseline height SDS, target and predicted height SDS showed an increase of 0.6 SDS (95\% CI 0.2 to $0.9 \mathrm{SDS}$ ) with the use of GnRH agonist. Translated into centimeters, the difference was $4.2 \mathrm{~cm}(95 \% \mathrm{CI}$ 1.7 to $6.7 \mathrm{~cm})$. There was no difference according to sex, although the results suggested a better effect in boys. The treatment was associated with a decrease in bone mineral density, measured 1 year after the discontinuation of the treatment.

Although one might view these results as discrepant, they are indeed very consistent and indicate that GnRH agonists have two effects, reducing the growth rate and the bone age progression, resulting in opposite effects on adult height. When these treatments are used for short periods of time (as in our study), the effect on adult height is close to zero since these two factors 
counterbalance each other. However, when duration of treatment increases, the slow growth rate observed in the absence of bone age progression eventually converts into increased adult height, roughly $1 \mathrm{~cm}$ per treatment year. In addition, other studies in children with 'premature' or 'early' puberty and decreased predicted height have made similar observations, i.e. that short treatments with GnRH agonists led to no or clinically insignificant adult height gains $(19,22,23)$. This is reminiscent of the increased adult height of patients with hypogonadism, only if untreated to the age of 20 years (24). Similarly, in males with estrogen receptor or aromatase deficiency, height is normal or low around the age of puberty in the absence of a growth spurt. However, persistent growth in the absence of growth plate fusion leads to tall stature when patients are older than 20 years $(8,25,26)$. The identification of non-endocrine factors involved in growth plate maturation will certainly increase our understanding of the relative importance of endocrine and non-endocrine factors.

In sum the data accumulated so far allow the clinician to give in-depth explanations to patients and families: short treatments are completely ineffective and long treatments have some efficacy with questionable clinical significance $(4 \mathrm{~cm})$ and serious safety concerns. In addition, the psychological sequelae of drug-induced severe pubertal delay have to be evaluated. Therefore, GnRH agonist treatments to increase height outside of precocious puberty are not currently advised outside research protocols $(21,27)$.

\section{GH in short children at onset of puberty}

GH is increasingly used in short children and is now approved in Europe for use in short children born small for gestational age. However, this indication covers a wide range of clinical situations and does not exclude the treatment of these short children when first seen around the age of puberty. We have obtained data relevant to this topic in two situations. First in analyzing a large cohort of children treated in France for idiopathic GH deficiency and secondly in a clinical trial aiming at improving adult height in children born small for gestational age.

In the first situation (28), we tried, by analyzing a population-based series of patients treated for $\mathrm{GH}$ deficiency, to evaluate the effect of GH on adult height. It could be viewed as paradoxical to use children with GH deficiency when elaborating on the effect of GH in idiopathic short stature. However, the mean age at onset of treatment (12.6 years) and the fact that more than $90 \%$ of the children had stimulated GH peaks over $5 \mathrm{ng} / \mathrm{ml}$ classifies them more accurately in the idiopathic short stature group than in the true GH-deficient group (29, 30). As shown in Fig. 2, we classified patients between those who had completed their treatment until the near-end of growth (roughly $50 \%$ of the 2852


Figure 2 Height outcome in short children treated with $\mathrm{GH}$ for $\mathrm{GH}$ deficiency: results of the France-Hypophyse database; reprinted from (28).

patients followed to adult height) and those who had stopped treatment at various time points before reaching this stage. In the direct analysis of data, all groups gained about 1.1 SDS, raising the question whether this was due to spontaneous catch-up in individuals with delayed puberty or to the effect of GH. In particular, patients who had used GH for the shortest period of time (less than 18 months) did similarly to those who used treatment for the longest periods. In multivariate analysis we tried to take into account several factors associated with growth, resulting in a model explaining 58\% of the variance of height gain expressed in SDS. Most of the factors identified were unrelated to the treatment and only $4 \%$ of variance was explained by treatment variables. Quite interestingly, completion and duration of the treatment had opposite effects, with children with 'incomplete' treatments gaining more and longer treatments associated with higher gains (28). The mean effect was close to $1 \mathrm{~cm}$ of adult height gain by year of treatment. Other than the limits of a multicenter observational study, the two caveats of our study are first the relative heterogeneity of the patients who were mostly selected by their height and their (unreliable) response to GH provocative stimuli (31) and the 
relatively low dose of $\mathrm{GH}$ used $(0.4 \mathrm{U} / \mathrm{kg}$ per week or $0.02 \mathrm{mg} / \mathrm{kg}$ per week).

In a completely different context, we evaluated the effect of relatively high doses of $\mathrm{GH}(1.4 \mathrm{U} / \mathrm{kg}$ per week or $0.067 \mathrm{mg} / \mathrm{kg}$ per day) in short adolescents born small for gestational age (32). The strengths of this study were to include a randomized untreated control group and that more than $\sim 90 \%$ of patients in the treated group were followed to adult height. Quite interestingly the initial features (other than the GH stimulation tests) where very similar to those of the GH-deficient children of the France-Hypophyse database. Here we could conclude that treatment had induced a height gain of 0.6 SDS with a $95 \%$ CI of 0.27 to 0.89 SDS, with an average duration of treatment of 2.7 years (Table 2, Fig. 3). The only independent variable associated with outcome (other than treatment itself) was bone age delay, confirming the validity of its use to predict adult height in short adolescents. Interestingly, the estimate of the effect (0.6 SDS in 2.7 years or $0.2 \mathrm{SDS} /$ year) is of the same order of magnitude as in the France-Hypophyse database, although the dose varies by 3-fold between the two studies, raising the question of the dose relationship.

Table 2 Adult height $(\mathrm{cm})$ in short adolescents born small for gestational age in a randomized GH or control study; adapted from (32), with permission from The Endocrine Society, copyright 2003. Values are means \pm S.D.

\begin{tabular}{lcc}
\hline & $\begin{array}{c}\text { Controls } \\
n=33\end{array}$ & $\begin{array}{c}\text { GH-treated } \\
n=91\end{array}$ \\
\hline Boys & $159 \pm 5$ & $162 \pm 7$ \\
Girls & $147 \pm 5$ & $151 \pm 5$ \\
\hline
\end{tabular}

Other studies have addressed similar questions and have obtained quite similar results $(33,34)$. Altogether, these results demonstrate that $\mathrm{GH}$ given alone can increase the pubertal growth spurt in short adolescents. Similar to our conclusions with GnRH agonists, the physician now has precise information to give to patients and families on what to expect from a GH treatment in such a situation. She or he can discuss the clinical significance of such height gains, given the fact that all attempts to demonstrate benefits of such height gains on psychosocial parameters have so far failed (35). She or he can also discuss the constraints and risks of such treatments and the uncertainties concerning longterm consequences (36-39). Also to be taken into account, but probably to be left to regulatory authorities, is the cost-benefit ratio of those approaches, and for instance, in our randomized study, the average current cost of treatment was estimated to be $100000 €(37000 €$ per year).

\section{Combination of GH and GnRH agonists in short adolescents}

The possibility to block pubertal development and skeletal maturation as a tool to increase the effect of $\mathrm{GH}$ treatment has long been considered. However, to date, we only have hints on the true efficacy of the combination, while the definitive trial evaluating this approach is still lacking. Hence, as mentioned above, the relative ease of use of $\mathrm{GnRH}$ agonists has made them a popular additive to $\mathrm{GH}$ treatments given within approved indications. For instance when looking at large databases of GH-treated children, the number also receiving GnRH agonists is rather significant: 249
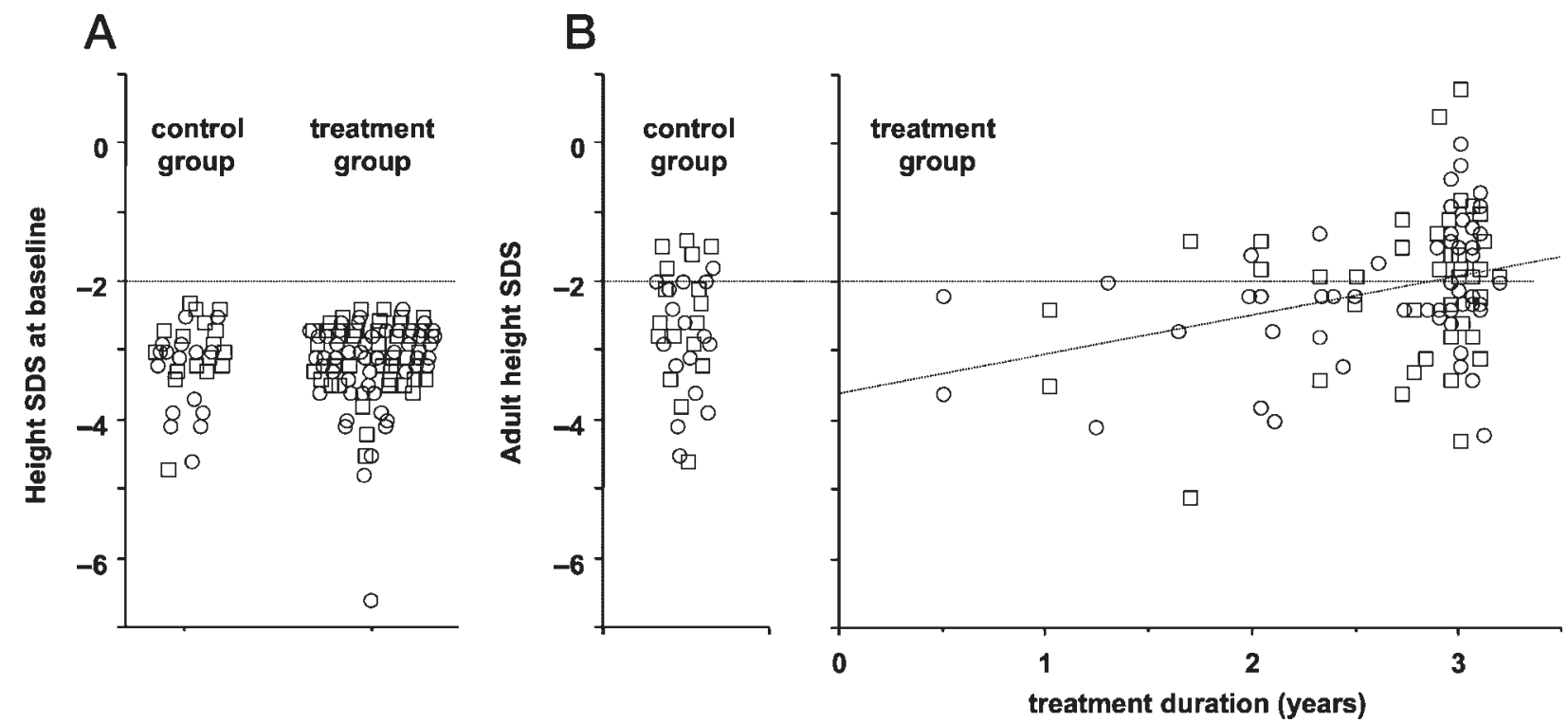

Figure 3 Height outcome in short adolescents born small for gestational age in a randomized GH or control study; boys and girls are represented by squares and circles respectively; reprinted from (32), with permission from The Endocrine Society, copyright 2003. 
of 21641 (1\%) in the KIGS database (40), 509 of 16000 (3\%) in the NCGS database (41), and in the FranceHypophyse database of 2852 children, $7 \%$ of boys and $11 \%$ of girls (28). It is noteworthy than since our study focused on patients having attained adult height, it selected older patients, artificially raising the proportion of those who had received GnRH agonists. The question of the efficacy of the combination is hard to address in observational databases. The KIGS study (40), by comparing the 39 of the 249 combination patients who were followed to near-adult height with 1893 treated with $\mathrm{GH}$ alone, observed a lower total height gain (from start of $\mathrm{GH}$ treatment to adult) in the combination patients than with GH alone ( -0.3 SDS in girls and -0.5 SDS in boys). We made a similar observation and, in multivariate analysis, use of GnRH agonist was associated with a 0.3 SDS decrease in adult height gain (28). However, looking further at the data, it became obvious that patients treated with the combination had poorer growth prognosis than those treated with $\mathrm{GH}$ alone. When introducing age at onset of puberty in the multivariate analysis, the influence of GnRH agonists disappeared, suggesting that the indication, not the treatment, was the cause for the decreased growth in those receiving the $\mathrm{GH}+\mathrm{GnRH}$ agonist combination. Other smaller studies have addressed the same question $(\mathrm{GH}+\mathrm{GnRH}$ agonist combination in $\mathrm{GH}$ deficiency), using patients selected from local or national databases or from small-scale trials (range 7-23 combination patients per study) $(42-45)$. The mean durations of the combination was quite variable ranging from 1.4 to 3 years. Most studies concluded at a benefit from the combination ranging from 0.8 to 1.4 SDS $(42-44)$. In one study there was no benefit for the entire group of patients, but subset analysis suggested some effect in patients born small

A

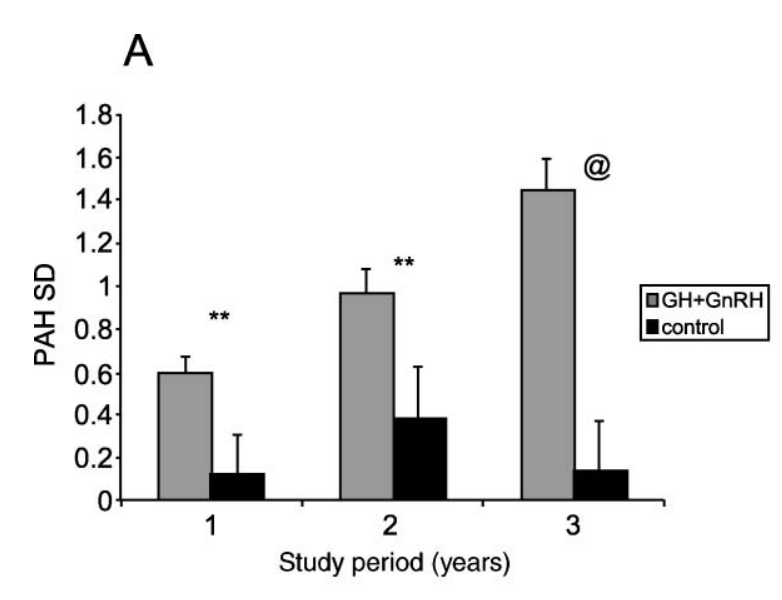

for gestational age (45). Altogether, we can derive no firm conclusion from these observational databases or small-scale studies, but observe that a high number of patients are so treated outside of the approved indication of GnRH agonists in children (precocious puberty).

Obviously the use of the combination of $\mathrm{GH}$ and $\mathrm{GnRH}$ agonists is a major focus of interest in children with normal endocrine status, with a diagnosis of idiopathic short stature or born small for gestational age. Although several studies have been produced showing variable effects, few of them have included a relevant control group (Fig. 4). Pasquino et al. (46) have compared 12 short normal girls treated with the combination vs 12 treated with GH alone. At adult height, the gain over predicted height was $10 \pm 2.9 \mathrm{~cm}$ with the combination vs $6.1 \pm 4.4 \mathrm{~cm}$ with $\mathrm{GH}$ alone, i.e. a mean difference of $4 \mathrm{~cm}$. In the Dutch study, 36 patients were randomized to combination treatment or observation (47). Although the final results have not been presented yet, predicted height at the end of the 3-year treatment period was higher by a mean of 1.2 SDS in the treated vs control group. These studies are encouraging but real adult height data have to be analyzed to really measure the effect of the combination treatment in short adolescents. Of course, in addition to the effectiveness of the approach in terms of centimeters, tolerance issues have to be addressed (does GH prevent GnRH agonist-induced loss of bone mass, etc?). The issues of clinical significance and cost effectiveness are the same as discussed above.

\section{Other approaches to increase adolescent growth}

Although GH and/or GnRH agonists have been the major focus of clinical research on pubertal growth in

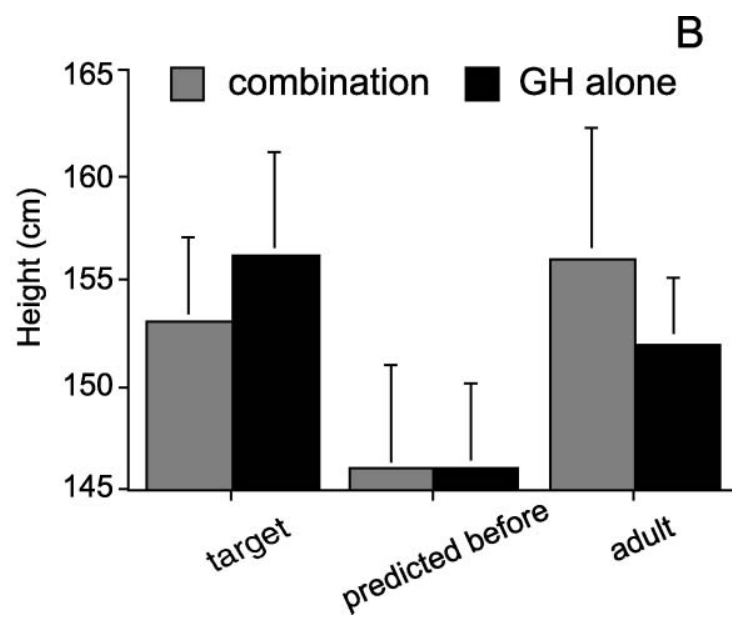

Figure 4 Height outcome in short adolescents treated with the combination of $\mathrm{GH}$ and $\mathrm{GnRH}$ agonists in a selected study. (A) Predicted adult height $(\mathrm{PAH})$ during treatment in the Dutch randomized control study; $\mathrm{GH}+\mathrm{GnRHa}, n=18$; controls, $n=16$; ${ }^{\star \star} P<0.05$;

${ }^{@} P<0.001 ;$ means \pm S.E.M. are shown. Adapted from Kamp et al. (47), with permission from The Endocrine Society, copyright 2001 ; (B) outcome in the study by Pasquino et al. (46); $n=12$ per group; mean \pm s.D. are shown. Adapted from (46), with permission from The Endocrine Society, copyright 2000. 
the past decade, other approaches have been proposed. Sex steroids are commonly used, in particular testosterone in boys, to hasten sexual maturation and increase growth in constitutional pubertal delay. Although these treatments are generally considered not to affect adult height, they meet the needs of most of the children seen for short stature at entry of puberty, i.e. correct their transient height deficit compared with their peers with normally timed puberty. These treatments are considered safe and are remarkably cheap in comparison with those discussed above (48). Their use has been discussed in several reviews $(49,50)$.

More recently, the use of aromatase inhibitors has been proposed to specifically decrease the growthmaturating effects of estrogens on the growth plate and therefore increase adult height (51). So far, these treatments have only been used in pediatric endocrinology in rare patients with gonadotropin-independent precocious puberty $(52,53)$. This approach has recently been reviewed elsewhere (54) and awaits further efficacy and safety data.

\section{Conclusion}

Although the current state of the art could look rather disappointing, with many questions remaining unanswered, we have gained insight into the median effects of some of these treatments and overoptimistic initial expectations are now refocused. However, we still have a long way to go before we truly evaluate the factors affecting the variable responses to these treatments, their clinical significance and their cost-benefit balance.

\section{References}

1 Coste J, Ecosse E, Lesage C, Chaussain JL \& Carel JC. Evaluation of adolescent statural growth in health and disease: reliability of assessment from height measurement series and development of an automated algorithm. Hormone Research $2002 \mathbf{5 8}$ 105-114.

2 Berkey CS, Dockery DW, Wang X, Wypij D \& Ferris B, Jr. Longitudinal height velocity standards for US adolescents. Statistics in Medicine $199312403-414$.

3 Biro FM, McMahon RP, Striegel-Moore R, Crawford PB, Obarzanek E, Morrison JA, Barton BA \& Falkner F. Impact of timing of pubertal maturation on growth in black and white female adolescents: The National Heart, Lung, and Blood Institute Growth and Health Study. Journal of Pediatrics 2001138 636-643.

4 Rogol AD. Early menarche and adult height: reprise of the hare and the tortoise? Journal of Pediatrics 2001138 617-618.

5 Vizmanos B, Marti-Henneberg C, Cliville R, Moreno A \& Fernandez-Ballart J. Age of pubertal onset affects the intensity and duration of pubertal growth peak but not final height. American Journal of Human Biology 200113 409-416.

6 Marshall WA \& Tanner JM. Variations in the pattern of pubertal changes in girls. Archives of Disease in Childhood $1969 \mathbf{4 4}$ 291-303.

7 Marshall WA \& Tanner JM. Variations in the pattern of pubertal changes in boys. Archives of Disease in Childhood 197045 13-24.
8 Grumbach MM \& Auchus RJ. Estrogen: consequences and implications of human mutations in synthesis and action. Journal of Clinical Endocrinology and Metabolism 199984 4677-4694.

9 He Q \& Karlberg J. BMI in childhood and its association with height gain, timing of puberty, and final height. Pediatric Research $200149244-251$.

10 Rousseau F, Bonaventure J, Legeai-Mallet L, Pelet A, Rozet JM, Maroteaux P, Le Merrer M \& Munnich A. Mutations in the gene encoding fibroblast growth factor receptor-3 in achondroplasia. Nature $1994371252-254$.

11 Bellus GA, McIntosh I, Smith EA, Aylsworth AS, Kaitila I, Horton WA, Greenhaw GA, Hecht JT \& Francomano CA. A recurrent mutation in the tyrosine kinase domain of fibroblast growth factor receptor 3 causes hypochondroplasia. Nature Genetics $199510357-359$.

12 Vajo Z, Francomano CA \& Wilkin DJ. The molecular and genetic basis of fibroblast growth factor receptor 3 disorders: the achondroplasia family of skeletal dysplasias, Muenke craniosynostosis, and Crouzon syndrome with acanthosis nigricans. Endocrine Reviews $20002123-39$.

13 Colvin JS, Bohne BA, Harding GW, McEwen DG \& Ornitz DM. Skeletal overgrowth and deafness in mice lacking fibroblast growth factor receptor 3. Nature Genetics $1996 \mathbf{1 2}$ 390-397.

14 Patten JL, Johns DR, Valle D, Eil C, Gruppuso PA, Steele G, Smallwood PM \& Levine MA. Mutations in the gene encoding the stimulatory G protein of adenylate cyclase in Albright's hereditary osteodystrophy. New England Journal of Medicine $1990 \mathbf{3 2 2}$ $1412-1418$

15 Weinstein LS, Yu S, Warner DR \& Liu J. Endocrine manifestations of stimulatory $\mathrm{G}$ protein alpha-subunit mutations and the role of genomic imprinting. Endocrine Reviews 200122 675-705.

16 Linglart A, Carel JC, Garabedian M, Le T, Mallet E \& Kottler ML. GNAS1 lesions in pseudohypoparathyroidism Ia and Ic: genotype phenotype relationship and evidence of the maternal transmission of the hormonal resistance. Journal of Clinical Endocrinology and Metabolism 200287 189-197.

17 van der Eerden BC, Karperien M \& Wit JM. Systemic and local regulation of the growth plate. Endocrine Reviews $2003 \mathbf{2 4}$ 782-801.

18 Carel JC, Lahlou N, Jaramillo O, Montauban V, Teinturier C, Colle M, Lucas C \& Chaussain JL. Treatment of central precocious puberty by subcutaneous injections of leuprorelin 3-month depot (11.25 mg). Journal of Clinical Endocrinology and Metabolism 2002 $874111-4116$.

19 Carel JC, Lahlou N, Roger M \& Chaussain JL. Precocious puberty and statural growth. Human Reproduction Update $2004 \mathbf{1 0}$ 135-147.

20 Carel JC, Hay F, Coutant R, Rodrigue D \& Chaussain JL. Gonadotropin releasing hormone agonist treatment of girls with constitutional short stature and normal pubertal development. Journal of Clinical Endocrinology and Metabolism $1996 \mathbf{8 1}$ 3318-3322.

21 Yanovski JA, Rose SR, Municchi G, Pescovitz OH, Hill SC, Cassorla FG \& Cutler GB, Jr. Treatment with a luteinizing hormone-releasing hormone agonist in adolescents with short stature. New England Journal of Medicine 2003348 908-917.

22 Lazar L, Kauli R, Pertzelan A \& Phillip M. Gonadotropin-suppressive therapy in girls with early and fast puberty affects the pace of puberty but not total pubertal growth or final height. Journal of Clinical Endocrinology and Metabolism $2002 \mathbf{8 7}$ 2090-2094.

23 Bouvattier C, Coste J, Rodrigue D, Teinturier C, Carel JC, Chaussain JL \& Bougneres PF. Lack of effect of GnRH agonists on final height in girls with advanced puberty: a randomized long-term pilot study. Journal of Clinical Endocrinology and Metabolism 1999 84 3575-3578.

24 Uriarte MM, Baron J, Garcia HB, Barnes KM, Loriaux DL \& Cutler GBJ. The effect of pubertal delay on adult height in men with 
isolated hypogonadotropic hypogonadism. Journal of Clinical Endocrinology and Metabolism 199274 436-440.

25 Smith EP, Boyd J, Frank GR, Takahashi H, Cohen RM, Specker B, Williams TC, Lubahn DB \& Korach KS. Estrogen resistance caused by a mutation in the estrogen-receptor gene in a man. New England Journal of Medicine 1994331 1056-1061.

26 Bilezikian JP, Morishima A, Bell J \& Grumbach MM. Increased bone mass as a result of estrogen therapy in a man with aromatase deficiency. New England Journal of Medicine 1998339 599-603.

27 Lee MM. Is treatment with a luteinizing hormone-releasing hormone agonist justified in short adolescents? New England Journal of Medicine $2003348942-945$.

28 Carel JC, Ecosse E, Nicolino M, Tauber M, Leger J, Cabrol S, BastiéSigeac I, Chaussian JL \& Coste J. Adult height after long-term recombinant growth hormone treatment for idiopathic isolated growth hormone deficiency: observational follow-up study of the French population-based registry. British Medical Journal $200232570-73$

29 Marin G, Domene H, Barnes K, Blackwell B, Cassorla F \& Cutler G Jr. The effects of estrogen priming and puberty on the growth hormone response to standardized treadmill exercise and arginine-insulin in normal girls and boys. Journal of Clinical Endocrinology and Metabolism 199479 537-541.

30 Rosenfeld RG, Albertsson-Wikland K, Cassorla F, Frasier SD, Hasegawa Y, Hintz RL, LaFranchi S, Lippe BM, Loriaux DL, Melmed S, Preece MA \& Ranke MB, Reiter EO, Rogol AD, Underwood LE \& Werther GE. Diagnostic controversy: the diagnosis of childhood growth hormone deficiency revisited. Journal of Clinical Endocrinology and Metabolism $1995801532-1540$.

31 Carel JC, Tresca J-P, Letrait M, Le Bouc Y, Job J-C, Chaussain JL \& Coste J. Growth hormone testing for the diagnosis of growth hormone deficiency in childhood: a population register-based study. Journal of Clinical Endocrinology and Metabolism $1997 \mathbf{8 2}$ 2117-2121.

32 Carel JC, Chatelain P, Rochiccioli P \& Chaussain JL. Improvement in adult height after growth hormone treatment in adolescents with short stature born small for gestational age: results of a randomized controlled study. Journal of Clinical Endocrinology and Metabolism 200388 1587-1593.

33 Hintz RL, Attie KM, Baptista J \& Roche A. Effect of growth hormone treatment on adult height of children with idiopathic short stature. New England Journal of Medicine $1999 \mathbf{3 4 0}$ 502-507.

34 Leschek EW, Rose SR, Yanovski JA, Troendle JF, Quigley CA, Chipman JJ, Crowe BJ, Ross JL, Cassorla FG, Blum WF, Cutler GB, Jr \& Baron J. Effect of growth hormone treatment on adult height in peripubertal children with idiopathic short stature: a randomized, double-blind, placebo-controlled trial. Journal of Clinical Endocrinology and Metabolism 200489 3140-3148.

35 Sandberg DE \& Voss LD. The psychosocial consequences of short stature: a review of the evidence. Best Practice and Research. Clinical Endocrinology and Metabolism 200216 449-463.

36 Juul A, Bernasconi S, Carel JC, Clayton PE, Kiess W \& DeMuinckKeizer Schrama S. Growth hormone treatment and risk of solid tumours. A statement from the Drugs and Therapeutics Committee of the European Society for Paediatric Endocrinology (ESPE). Hormone Research 200360 103-104.

37 Swerdlow AJ, Higgins CD, Adlard P \& Preece MA. Risk of cancer in patients treated with human pituitary growth hormone in the UK, 1959-1985: a cohort study. Lancet $2002360273-277$.

38 Sperling MA, Saenger PH, Ray H, Tom W \& Rose SR. Growth hormone treatment and neoplasia - coincidence or consequence? Journal of Clinical Endocrinology and Metabolism $2002 \quad 87$ $5351-5352$.

39 Wilson TA, Rose SR, Cohen P, Rogol AD, Backeljauw P, Brown R, Hardin DS, Kemp SF, Lawson M, Radovick S, Rosenthal SM, Silverman L \& Speiser P. Update of guidelines for the use of growth hormone in children: the Lawson Wilkins Pediatric
Endocrinology Society Drug and Therapeutics Committee. Journal of Pediatrics 2003143 415-421.

40 Reiter EO, Lindberg A, Ranke MB, Price DA, Albertsson-Wikland $\mathrm{K}$, Cowell CT et al. The KIGS experience with the addition of gonadotropin-releasing hormone agonists to growth hormone (GH) treatment of children with idiopathic GH deficiency. Hormone Research 200360 (Suppl 1) 68-73.

41 Kohn B, Julius JR \& Blethen SL. Combined use of growth hormone and gonadotropin-releasing hormone analogues: the national cooperative growth study experience. Pediatrics $1999 \quad 104$ 1014-1018.

42 Mericq MV, Eggers M, Avila A, Cutler GB Jr \& Cassorla F. Near final height in pubertal growth hormone (GH)-deficient patients treated with $\mathrm{GH}$ alone or in combination with luteinizing hormone-releasing hormone analog: results of a prospective, randomized trial. Journal of Clinical Endocrinology and Metabolism $200085569-573$.

43 Saggese G, Federico G, Barsanti S \& Fiore L. The effect of administering gonadotropin-releasing hormone agonist with recombinant-human growth hormone $(\mathrm{GH})$ on the final height of girls with isolated GH deficiency: results from a controlled study. Journal of Clinical Endocrinology and Metabolism 200186 1900-1904.

44 Mul D, Wit JM, Oostdijk W \& Van den Broeck J. The effect of pubertal delay by GnRH agonist in GH-deficient children on final height. Journal of Clinical Endocrinology and Metabolism $2001864655-4656$.

45 Tauber M, Berro B, Delagnes V, Lounis N, Jouret B, Pienkowski C et al. Can some growth hormone (GH)-deficient children benefit from combined therapy with gonadotropin-releasing hormone analogs and GH? Results of a retrospective study. Journal of Clinical Endocrinology and Metabolism 200388 1179-1183.

46 Pasquino AM, Pucarelli I, Roggini M \& Segni M. Adult height in short normal girls treated with gonadotropin-releasing hormone analogs and growth hormone. Journal of Clinical Endocrinology and Metabolism $200085619-622$.

47 Kamp GA, Mul D, Waelkens JJ, Jansen M, Delemarre-van de Waal HA, Verhoeven-Wind L, Frolich M, Oostdij K \& Wit JM. A randomized controlled trial of three years growth hormone and gonadotropin-releasing hormone agonist treatment in children with idiopathic short stature and intrauterine growth retardation. Journal of Clinical Endocrinology and Metabolism $2001862969-2945$.

48 Kelly BP, Paterson WF \& Donaldson MD. Final height outcome and value of height prediction in boys with constitutional delay in growth and adolescence treated with intramuscular testosterone $125 \mathrm{mg}$ per month for 3 months. Clinical Endocrinology $2003 \mathbf{5 8} 267-272$.

49 Reiter EO \& Lee PA. Delayed puberty. Adolescent Medicine 200213 101-118.

50 Kulin HE. Delayed puberty. Journal of Clinical Endocrinology and Metabolism $1996 \mathbf{8 1} 3460-3464$.

51 Wickman S, Sipila I, Ankarberg-Lindgren C, Norjavaara E \& Dunkel L. A specific aromatase inhibitor and potential increase in adult height in boys with delayed puberty: a randomised controlled trial. Lancet 2001357 1743-1748.

52 Feuillan P, Merke D, Leschek EW \& Cutler GBJ. Use of aromatase inhibitors in precocious puberty. Endocrine-Related Cancer 1999 $6303-306$

53 Leschek EW, Jones J, Barnes KM, Hill SC \& Cutler GBJ. Six-year results of spironolactone and testolactone treatment of familial male-limited precocious puberty with addition of deslorelin after central puberty onset. Journal of Clinical Endocrinology and Metabolism 199984 175-178.

54 Dunkel L \& Wickman S. Novel treatment of short stature with aromatase inhibitors. Journal of Steroid Biochemistry and Molecular Biology 200386 345-356.

Received 12 August 2004

Accepted 23 September 2004 